\title{
The Value of Water in the Manufacture Industry and its Implications for Water Demand Policies. The Case of Chile*
}

\author{
MigUEL ÁNGEL TOBARRA-GONZÁLEZ \\ Universidad Politécnica de Cartagena, Facultad de Ciencias de la Empresa, C/ Real, 3, 30201- \\ Cartagena (Murcia), España. E-mail: miguel.tobarra@upct.es
}

\begin{abstract}
This paper studies the use of water in the manufacture industry of Chile using cross section data of 2,339 firms. A translog production function has been estimated in order to obtain important indicators as marginal productivity water value and demand price elasticity. A marginal value for water of 1,508.6 pesos per $\mathrm{m}^{3}$ (1.99 euros, 2.64 USD) has been obtained for the whole manufacture industry although there are important differences between sectors. Industrial water demand is elastic since price elasticity calculated is 1.1. This indicates that tariff policy can be a proper instrument to get water savings in the manufacture industry of Chile.
\end{abstract}

Keywords: Industrial Water Demand; Marginal Value of Water; Water Markets.

\section{Valor del agua en la industria manufacturera de Chile y sus implicaciones para las políticas de demanda de agua}

\begin{abstract}
RESUMEN
Este artículo estudia el uso del agua en la industria manufacturera de Chile usando una muestra de 2.339 empresas. Se ha estimado una función de producción translog para obtener importantes indicadores como el valor marginal del agua y la elasticidad precio de la demanda de agua. El valor marginal del agua estimado en este sector es de 1.508,6 pesos por $\mathrm{m}^{3}$ (1,99 euros, 2,64 dólares de Estados Unidos) aunque hay diferencias importantes entre los subsectores que lo conforman. El valor estimado de la elasticidad precio de la demanda de agua en la industria manufacturera es de 1,1 por lo que la política tarifaria es un instrumento adecuado para conseguir ahorros en el consumo de este sector.

Palabras clave: Demanda de agua industrial, valor marginal del agua, mercados de agua.
\end{abstract}

JEL Classification: D24, Q25

\footnotetext{
* This study is part of the project AGL2013-48080-C2-2-R, supported by Ministerio de Economía y Competitividad and Fondo Europeo de Desarrollo Regional (FEDER)
}

Artículo recibido en mayo de 2018 y aceptado en agosto de 2018

Artículo disponible en versión electrónica en la página www.revista-eea.net, ref. ə-36304 


\section{INTRODUCTION}

In case of water scarcity, and once that households needs and environmental constrains are covered, water should be assigned to the most valuable use although equity criterions should also be taken into account. So, Knowledge of water demand and its value in all economic sectors is necessary for a proper water resources management. While there is substantial literature dealing with the agricultural and domestic water demand, relatively few papers have analysed industrial case ${ }^{1}$. Nonetheless, its study is important for several reasons. Firstly, it supposes an important part of water capture that will probably increase in quantity (Féres and Reynaud 2005) and proportion (Dupont and Renzetti 2001, quoting Biswass 1997). Secondly, water is necessary for the industrial and economic development of countries and sometimes it conditions it (Gibbons 1986). Thirdly, it is an important source of pollution in the absence of a proper treatment (Féres, Reynaud and Thomas 2012). Finally, measuring the value of water in the different uses that compete for it (households, agriculture, industry, recreation and environment) is necessary for an appropriate hydric management (Viljoen et al., 2000).

The issue of assessing the value of water for industrial firms remains open in many countries (Reynaud 2003). One difficulty is the absence of microdata to carry out this kind of surveys. In this paper, we are going to focus in Chile since an important data base is available. The sample of 2339 firms used in this paper constitutes the largest sample used in a survey about industrial water use. The scarcity of water industrial use studies for countries of America (excluding USA, Brazil and Canada) make also very advisable this kind of study.

Manufacture industry supposed $11.2 \%$ of the Domestic Gross Product (GDP) of Chile in 2012. Within it, Food, Beverage and Tobacco has the greatest weight and supposed 36\% of industrial GDP of Chile that year. Other important subsectors are Chemistry, oil, couch and plastics that supposed $20.3 \%$ of industrial GDP, Metal products, machinery and equipment that supposed 19.2\% and Cellulose, paper and prints that supposed 10.1\%. Recently, industrial production of Chile, increased from 2003 to 2007, decreased from 2008 to 2010 and increased again in 2011 and 2012.

As National Resources Strategy 2012-2025 points out, industry supposes nowadays $12 \%$ of consumption water uses in Chile; agriculture supposes $73 \%$, Mining 9\% and households supply 6\%.

\footnotetext{
${ }^{1}$ Olmstead (2010), in a survey about the scarce water resource management only references Ziegler and Bell (1984), Renzetti (1992) and Reynaud (2003), included in Griffin (2006). Other issues about water management have been approached as, for example, water quality measurement by indicators and its relationship with tariffs (Beamonte et al., 2010), households water supply prices (Del Villar 2010), environmental taxes and renewable energies as a decontamination tool, Román et al. (2013) or municipalities water demand (Tobarra-González 2013), between many others.
} 
The majority of the scarce studies about industrial water demand develop an analysis from the cost functions perspective, what allows us to obtain price elasticity of industrial water demand and substitutive or complementary relationships between water and other production factors. In this study, industrial water demand analysis will be made from an industrial production function perspective, what will allow us to obtain important indicators for a proper hydric management. These are marginal value of water for industrial use, price water demand elasticity and production elasticity of water production factor in this sector. Marginal value of water for industrial use in Chile is a major result and gives us information about willingness to pay for water in this sector. Price water demand elasticity in industry shows how sensitive is industrial water demand to tariffs raise and so it is an indicator of tariff policy effectiveness to reduce consumption.

After this introduction, this paper is organized in the following way. Section 2 revises bibliography about industrial water demand. Section 3 introduces the model to estimate and available data for the industry sector of Chile. Section 4 estimates the model and presents major results. Finally, section 5 concludes.

\section{INDUSTRIAL WATER DEMAND PAST RESEARCH}

Related to industrial water use we could distinguish four groups of papers. The first one is related to industrial water demand. These papers mainly focus on the variables that determine industrial water demand, the variable used as water price and the relationships between water and other production factors. Between them, we could mention Turnovsky (1969), DeRooy (1974), Grebenstein and Field (1979), Babin et al. (1982), Ziegler and Bell (1984) and Williams and Suh (1986). A second group studies complexity of water use in the industrial production process since water can be supplied by different sources. In this way we could distinguish between different water inputs that can act as complementary or substitute. In this group we could include, between others, Renzetti (1988), Renzetti (1992), Dupont and Renzetti (2001) and Arbués et al. (2010). A third group focus on environmental aspects of water use in the industry. Included in this group are, between others, Reynaud (2003), Féres and Reynaud (2005) and Féres et al. (2012). Finally, one fourth group focus on value of water. We can distinguish surveys that study the value of water in different sectors as Gibbons (1986) or Moran and Dann (2008) and others specialized in the industrial sector as Kumar (2006) or Wang and Lall (2002). It is in this last group in which this survey can be included.

A brief description of these cited papers is included below.

Turnovsky (1969) and DeRooy (1974) estimate industrial water demand models with only one equation using data of an individual industry or town. The first one points out water demand depends on supply variability, water average 
price and a production per capita index of the town. The second one, with a sample of 30 big plants, finds that water demand is sensitive to price, to output changes, technological improvements and employment. Both of them use the ratio between water expenses and quantity of water used as water price. Ziegler and Bell (1984) estimate water demand using a sample of self-supplied firms in the Paper and Chemistry sectors. They use average cost as water price. Grebenstein and Field (1979) and Babin et al. (1982) also use ex post average cost as a proxy for price. Nonetheless, Teeples and Glyer (1987) and Renzetti (1992) criticize this approach since it introduces the possibility of a simultaneity bias in the regression equation.

Williams and Suh (1986) obtain demand functions estimated by ordinary least squares from data of 120 municipalities of the United States. These depend on price, production value in each municipality and the number of industrial connections. They use five price specifications (first block marginal price, average price and the expense associated to three consumption levels) varying price elasticity with them. After estimating different models, they use Ramsey (1974) procedure based on specification error test to choose the model with the most appropriate price specification. They conclude that marginal specification is preferred to average.

Major results of these studies about industrial water demand are the following: price elasticities are small but, in general, higher than household use ones; elasticity estimates depend on the industry considered; water and labour are substitute while capital and water complementary inputs.

Renzetti (1988) was the first author that tried to introduce the complexity of water use in the industrial production process. He distinguished intake, treatment prior to use, internal re-circulation and discharge as four different inputs. He used a sample of 372 firms that belonged to four manufacture sectors and concluded that intake and treatment prior to use are complementary inputs and intake and internal recirculation are substitute inputs. Renzetti (1992) used the same model with a sample of 2000 firms that belonged to seven industrial manufacture sectors in Canada. He uses a cost function approximated by a translog form and conditional factor demands are derived using Shephard lemma. They conclude that intake and re-circulation are substitutive factors. This way in which water is not a unique factor but different ones depending on the source is followed in other works as Dupont and Renzetti (2001). These last authors calculate inputs demands elasticity with respect to the level of output of the firm and inputs demand price elasticity and they find that intake and recirculation are substitute inputs.

Arbués et al. (2010) study water demand for industrial and services uses connected to municipality's nets in the town of Zaragoza (Spain). They use a dynamic adjustment Koyck model. They obtain an inelastic demand although 
sensitivity to price is greater than the ones that households have due probably to the existence of alternative supply sources in this town and the recycling possibility. They also point out that the perceived price by these users is lower than the one that they really pay.

Reynaud (2003) has firstly taken into account polluted water in the production process as he considers this as a byproduct of this process. He finds that water bought to a supplier and the one captured by the firm are complementary inputs and water bought to a supplier and water treated before use substitutive.

Féres and Reynaud (2005) assess the impacts of environmental policies on industrial water use in Brazil. They point out that water charge is an effective tool for conserving the resource due to water demand price elasticity and the low impact of tariff increments on firm costs. Nonetheless, this can cause an increment in energy costs. On the other side, reducing pollution index (due to more demanding environment standards) would imply greater water consumption.

Féres et al. (2012) study what factors influence in the decision of reusing water in the industry and they analyze if the structure of water demand is different between the firms that adopt reuse practices and those that do not do it. They use a model with a demand equation for plants that reuse and other for the ones that do not reuse water besides a probit type decision equation. They conclude that water tariffs can be used as an effective mechanism to induce firms to invest in water reuse, and so reduce intakes, and that plants that reuse water are more sensitive to water tariffs increments.

Most of papers devoted to industrial water demand study use cost functions from which they obtain water derived demand in the industry. Between them, the cost functional form most used is the translog as in Grebenstein and Field (1979), Babin et al. (1982), Renzetti (1992), Dupont and Renzetti (2001), Reynaud (2003) and Feres and Reynaud (2005). A Cobb-Douglas form is also frequently used as in De Roy (1974), Ziegler and Bell (1984), Renzetti (1993), Arbués et al. (2010) and Féres et al. (2012).

Kumar (2006) and Wang and Lall (2002) make an analysis in which information about input prices is not necessary unlike the case of cost function approach. Kumar (2006) use an input distance function approach in which it is not necessary to maintain the minimization cost hypothesis. He obtains an average shadow price of water of 7.21 Rupees per kiloliter. Wang and Lall (2002) use production functions that allow them to obtain production elasticity, marginal productivity and value of water. This last one is the approach that is going to be used in this study. Data available does not allow a cost function approach since there is no information about prices of inputs. 


\section{MODEL TO ESTIMATE AND DATA}

One production function shows the relationship between the output or production of a firm and the production factors or inputs used in the process. In this paper, water, capital, labour, electric energy, other sources of energy and raw materials, are treated as inputs of the production function. Production elasticity, marginal value of water and water price elasticity for industrial use can be obtained from the production function. This production or productivity approach is the dual of cost function approach since marginal cost should be equal to marginal value of production if it is accepted that firms maximize profits.

\subsection{Model specification}

One production function can be built as $X=F(W, K, L, E, E N, M)$ where $X$ is the output or production, $\mathrm{W}$ is water, $\mathrm{K}$ is capital, $\mathrm{L}$ is labour, $\mathrm{E}$ is electric energy, EN other sources of energy and M is raw materials. One production function usually used in economic studies is the Cobb-Douglas but given its restrictions, as assumptions of additivity and homogeneity, it will be used the alternative representation proposed by Christensen et al., 1973, the following translog approximation ${ }^{2}$.

$$
\begin{aligned}
& \ln X=\propto_{0}+\propto_{1} \ln W+\propto_{2} \ln K+\propto_{3} \ln L+\propto_{4} \ln E+\propto_{5} \ln E n+\propto_{6} \ln M+ \\
& +\propto_{7} \frac{\ln ^{2} W}{2}+\propto_{8} \frac{\ln ^{2} K}{2}+\propto_{9} \frac{\ln ^{2} L}{2}+\propto_{10} \frac{\ln ^{2} E}{2}+\propto_{11} \frac{\ln ^{2} E n}{2}+\propto_{12} \frac{\ln ^{2} M}{2}+ \\
& \propto_{13} \ln W \ln K++\propto_{14} \ln W \ln L+\propto_{15} \ln W \ln E+\propto_{16} \ln W \ln E n+ \\
& \propto_{17} \ln W \ln M+\propto_{18} \ln K \ln L++\propto_{19} \ln K \ln E+\propto_{20} \ln K \ln E n+ \\
& \propto_{21} \ln K \ln M+\propto_{22} \ln L \ln E+\propto_{23} \ln L \ln E n++\propto_{24} \ln L \ln M+ \\
& \propto_{25} \ln E \ln E n+\propto_{26} \ln E \ln M+\propto_{27} \ln E n \ln M+\epsilon
\end{aligned}
$$

where:

- Ln X is log of production.

- Ln W is log of water used in the industrial production process.

- Ln $\mathrm{K}$ is log of capital.

- Ln L is log of labour.

- Ln E is log of electric energy.

\footnotetext{
${ }^{2}$ The origin of the work on production function can be attributed to Cobb and Douglas (1928), who tested that production could be governed by proportions of productive factors. The Cobb-Douglas production function has been very used. The translog production function has been also very used and provides a greater variety of substitution of transformation patterns than those restricted by constant elasticity of substitution.
} 
- Ln En is log of other sources of energy (different to electric energy).

- Ln M is log of raw material.

The elasticity of production with respect to each production factor is calculated by taking the partial derivative of output with respect to the factor under consideration. For the water case, elasticity $(\in)$ can be derived as:

$\in=\frac{\partial \ln X}{\partial \ln W}=\propto_{1}+\propto_{7} \ln W+\propto_{13} \ln K+\propto_{14} \ln L+\propto_{15} \ln E+\propto_{16} \ln E n+\propto_{17} \ln M$

Marginal productivity of water $(\rho)$ in industrial production is calculated as:

$$
\rho=\frac{\partial X}{\partial W}=\frac{\partial \ln X}{\partial \ln W} * \frac{X}{W}=\epsilon \frac{X}{W}
$$

If $\mathrm{X}$ is total value of industrial production, equation [3] gives marginal value of water for industrial use.

Price elasticity of water used $(\tau)$ can also be derived if water price is assumed to be set equal to the marginal value of water use. So,

$$
\tau=\frac{\partial \ln W}{\partial \ln P}=\frac{\partial \ln W}{\partial \ln \rho}=-\frac{\epsilon}{\epsilon-\epsilon^{2}-\alpha_{7}}
$$

Calculus of these concepts with available data will allow to obtain some useful results for the industry of Chile and a proper management of water natural resource.

\subsection{Data}

Data comes from Encuesta Industrial de Empresas, year 2012, published by National Statistical Institute of Chile ${ }^{3}$, from which a sample of 2.339 firms of the manufacture industry sector of Chile is used. This figure constitutes a very good standard because none of the papers cited has such a wide sample and only two of them have a sample with more than 2.000 firms, the cross sectional surveys by Renzetti (1992) and Wang and Lall (2002).

So, production variable $(\mathrm{X})$ is total firm revenue in thousands of pesos of Chile. Water variable (W) is water consumption in thousands of $\mathrm{m}^{3}$ (bought or taken from own sources); Capital variable (K) is capital stock in thousands of pesos; Labour variable ( $\mathrm{L}$ ) is the number of workers; Electric energy variable (E) is MWh used by the firm; other sources of energy variable (En) is the expense in other sources of energy different to electricity (oil, coal, wood...). Finally, raw materials variable (M) is raw material and materials used in the productive process. All these variables are referred to 2012 year. Table 1 in the

\footnotetext{
${ }^{3}$ Estos datos están disponibles en http://www.ine.cl/estadisticas/economicas/manufactura
} 
Annex informs the units, average value and standard deviation of the variables used in the estimate.

Once data have been presented, next section includes estimates made with them.

\section{MODEL ESTIMATE AND MAJOR RESULTS}

The cross-section model [1] is estimated by least squares. Results are shown in Table 1 below.

Table 1

Model [1] estimate

\begin{tabular}{|c|c|c|c|c|}
\hline Variable & Coefficient & Std. Error & t-Statistic & Prob. \\
\hline $\mathrm{C}$ & 7.729039 & 0.370812 & 20.84356 & 0.0000 \\
\hline LnW & 0.116142 & 0.042544 & 2.729937 & 0.0064 \\
\hline LnK & 0.173188 & 0.042379 & 4.086608 & 0.0000 \\
\hline LnL & 1.397272 & 0.086520 & 16.14964 & 0.0000 \\
\hline LnEN & 0.044172 & 0.045817 & 0.964106 & 0.3351 \\
\hline LnE & 0.018877 & 0.037750 & 0.500063 & 0.6171 \\
\hline LnM & -0.475742 & 0.050413 & -9.436934 & 0.0000 \\
\hline $\mathrm{Ln}^{2} \mathrm{~W} / 2$ & 0.001188 & 0.003697 & 0.321398 & 0.7479 \\
\hline $\mathrm{Ln}^{2} \mathrm{~K} / 2$ & -0.007470 & 0.002248 & -3.322307 & 0.0009 \\
\hline $\mathrm{Ln}^{2} \mathrm{~L} / 2$ & 0.104179 & 0.016399 & 6.352818 & 0.0000 \\
\hline $\mathrm{Ln}^{2} \mathrm{EN} / 2$ & 0.018809 & 0.004871 & 3.861227 & 0.0001 \\
\hline $\mathrm{Ln}^{2} \mathrm{E} / 2$ & 0.003134 & 0.004005 & 0.782443 & 0.4340 \\
\hline $\mathrm{Ln}^{2} \mathrm{M} / 2$ & 0.148394 & 0.005536 & 26.80381 & 0.0000 \\
\hline LnWLnK & -0.000431 & 0.003585 & -0.120254 & 0.9043 \\
\hline LnWLnL & -0.003317 & 0.006890 & -0.481504 & 0.6302 \\
\hline LnWLnEN & -0.008166 & 0.003615 & -2.259317 & 0.0240 \\
\hline LnWLnE & 0.005920 & 0.003698 & 1.600944 & 0.1095 \\
\hline LnWLnM & -0.003419 & 0.004687 & -0.729465 & 0.4658 \\
\hline LnKLnL & 0.020340 & 0.007990 & 2.545549 & 0.0110 \\
\hline LnKLnEN & 0.004013 & 0.003695 & 1.086223 & 0.2775 \\
\hline LnKLnE & 0.006629 & 0.003410 & 1.943855 & 0.0520 \\
\hline LnKLnM & -0.012478 & 0.004422 & -2.822118 & 0.0048 \\
\hline LnLLnEN & -0.001249 & 0.007698 & -0.162213 & 0.8712 \\
\hline LnLLnE & -0.004670 & 0.007171 & -0.651196 & 0.5150 \\
\hline LnLnM & -0.122082 & 0.008538 & -14.29868 & 0.0000 \\
\hline LnENLnE & 0.012217 & 0.003869 & 3.157551 & 0.0016 \\
\hline LnENLnM & -0.019181 & 0.004757 & -4.032176 & 0.0001 \\
\hline LnELnM & -0.017544 & 0.004413 & -3.975597 & 0.0001 \\
\hline R-squared & 0.955156 & \multicolumn{2}{|l|}{ S.D. dependent var } & 1.705061 \\
\hline Adjusted R-squared & 0.954632 & \multicolumn{2}{|l|}{ Akaike info criterion } & 0.824024 \\
\hline S.E. of regression & 0.363173 & \multicolumn{2}{|l|}{ Schwarz criterion } & 0.892946 \\
\hline Sum squared resid & 304.8084 & \multicolumn{2}{|l|}{ F-statistic } & 18023.08 \\
\hline Log likelihood & -935.6957 & \multicolumn{2}{|l|}{ Prob (F-statistic) } & 0.000000 \\
\hline Durbin-Watson stat & 1.901998 & & & \\
\hline
\end{tabular}

Source: Own elaboration. 
Model has a good adjustment as $\mathrm{R}^{2}$-adjusted, Akaike and Schwarz statistics show. Water, capital, labour, raw materials and others sources of energy are significant. Electric energy is not significant but it will be maintained because it is significant in some subsectors estimates made below ${ }^{4}$.

The values for elasticity of production with respect to water $(\epsilon)$, marginal value of water for industrial use $(\rho)$ and price elasticity of water used $(\tau)$, can be obtained from coefficients estimates and [2], [3] and [4] equations. These are $0.01577821,1,508.66$ pesos of Chile per $\mathrm{m}^{3}$ and -1.1 (calculated with average values of variables) from which some implications for water policies can be deduced.

If the elasticity of production with respect to water has a value of 0.01577821 , this means that an increment of $1 \%$ in the quantity of water used could increment production in $0.0157 \%$. So, important increments in industrial water demand can be foreseen if industrial output increases. Nonetheless, there are important differences between subsectors. An increment of $1 \%$ in the quantity of water used could increment production in $0.066 \%$ in the Cellulose, paper and prints sector and only $0.0005 \%$ in Textile, garments and leather sector.

The marginal value of water for industrial use is $1,508.66$ pesos of Chile (2.8 United States of America dollars; USD in the following) per $\mathrm{m}^{3}$. This would be maximum willingness to pay for an extra unit of water (one $\mathrm{m}^{3}$ more) in the manufacture industry of Chile. As water markets is an instrument available in water laws of Chile, and transactions can be made without significant restrictions, it is foreseeable a transfer from agrarian sector, that has a smaller willingness to pay for water (as it will be shown below), to the industrial sector in cases of scarcity as droughts ${ }^{5}$.

Finally, industrial water demand is elastic. A $10 \%$ increment of industrial water tariff would get to reduce $11 \%$ water consumption in the industry of Chile. So, tariff policy is a good instrument to get reductions in water consumption in the industry although firms would suffer an increment in water expenses. Nevertheless, it can be tolerable if water cost was not an important part of total production costs. It has to be emphasized that tariffs are an appropriate tool to guide water consumption to a proper targeted level.

\footnotetext{
${ }^{4}$ All these variables have been significant in the Cobb-Douglas model estimate included in Table 2 in the Annex. Nonetheless, the translog approximation model [1] is preferred as $\mathrm{R}^{2}$-Square, Akaike and Schwarz statistics show.

${ }^{5}$ This is the expected result of market implementation in case of scarcity. Nonetheless, causality tests could be made with apropiate data, especially to confirm a transfer from agricultural sector to industry. Paelinck and Mur (2018) highlight that the notion of cause is of paramount importance in any specification and they approach some issues on causality in spatial econometric models.
} 
Now, an analysis for subsectors will be shown. Econometric results are not included here but are available at request. The values of the three concepts studied are included in Table 3 in the Annex.

Wood and furniture shows the greatest marginal value of water $(13,447$ pesos for one $\mathrm{m}^{3}$ more) and Cellulose, paper and prints shows the lowest (only 1,017 pesos of Chile). Wood and furniture would be the best bidder, followed by Metal products, machinery and equipment and Chemistry, couch and plastics if water markets were implemented, and they would receive water transfers from other sectors. The results of this study can help to foresee the results of water markets implementation and so, they could help to a market regulation if there are any advisable water consumption quotas in case of scarcity.

Water demand is elastic in Food and Beverage, Cellulose, paper and prints and Wood and furniture and inelastic in the others, although with relatively high values. So, tariff policy can be considered as an effective instrument in all subsectors but especially in Cellulose, paper and prints where a $10 \%$ increment in tariff would get to reduce $30 \%$ water demand. Nonetheless, this last sector had only 187 firm data available for estimates.

So, in case of scarcity, and given that willingness to pay for water can act, since water markets are an instrument available, we could foresee a transfer of resources from industrial sectors in which water value is smaller to those that had a greater one. But given that the marginal value of water in all industrial sectors seems greater than marginal value of water in the agrarian sector, a transfer of water resources from the agrarian sector to the industrial one is foreseeable. We could deduce it after revising other surveys made for the agrarian sector.

In the case of agrarian sector in Chile there are not data available to this author to make an estimate of marginal value of water following the methodology described in section 3, so it is necessary to obtain some information from the studies applied to the agriculture of Chile. Rosegrant et al. (2000) introduced an economic-hydrologic model solved by mathematical programming (GAMS) and obtained shadow prices for water for eight irrigation districts in the Maipo River Basin; they vary from 0.099 to 0.177 USD per $\mathrm{m}^{3}$. These shadow prices could be interpreted as marginal values for water. Cai et al. (2008) estimate that, in the Maipo River basin, moving from the current input-constrained situation to full optimization of water resources would lead to an increase in all crop inputs. In this case, they calculate an additional water use of 301 million $\mathrm{m}^{3}$ that results in additional net profits of USD 11 million. This means that each extra $\mathrm{m}^{3}$ produces a profit of USD 0.036. So, although the quantity of the increment in water used is very large, we can deduce that marginal value of water in this sector is quite reduced compared to industrial marginal value. 
Other surveys in other countries that apply different methodologies also show smaller willingness to pay for water in the agrarian sector. Calatrava Leyva and Sayadi (2005) obtained a maximum willingness to pay of 0.6 euros per $\mathrm{m}^{3}$ by tropical fruit growers in Granada, Spain, and estimate the average marginal income value of water to be between 1.52 and 1.62 euros per $\mathrm{m}^{3}$. Albiac et al. (2006) reported an estimated average value product of water for agriculture of 0.75 euros per $\mathrm{m}^{3}$ in southeast Spain. Rigby et al. (2010) examined economic value of irrigation water for horticultural producers in southern Spain and they obtained a mean willingness to pay of 0.45 euros per $\mathrm{m}^{3}$. Carpio et al. (2011) obtained farmers in Jordan were willing to accept USD 0.16 per $\mathrm{m}^{3}$. Calatrava and Garrido (2005) obtained equilibrium prices for the agrarian water markets up to 0.3 euros for $\mathrm{m}^{3}$ in the Guadalquivir Valley (Southern Spain).

As these results show, marginal value of water in industry seems to be greater than agrarian marginal value of water in Chile. This would imply that water markets would redistribute water from the agrarian sector to the industry in case of scarcity of water.

\section{CONCLUSIONS}

Given the growing scarcity and increasing competition for water across sectors (households, industry, agriculture and environmental and recreation uses), the need for efficient, equitable and sustainable water allocation has increased in importance in water management. The limits of supply policies make demand policies (between them water markets and tariff policy) the only instruments available and also the most efficient in many cases.

In this paper, a production function estimate has been used to study industrial water use in Chile. Three important indicators have been obtained with significant implications for water management. These are elasticity of production, marginal value of water and price elasticity of water demand in industrial sector.

The value of elasticity of industrial production with respect to water obtained would imply that important increments in industrial water demand can be foreseen if industrial output increases. This indicator estimate shows that an increment of $1 \%$ in the quantity of water used could increment production in $0.0157 \%$. Nevertheless, there are important differences between sectors, being Cellulose, paper and prints and Wood and furniture, the sectors with a most sensitive water consumption to production increments.

The marginal value of water estimated has been 1,508.66 pesos of Chile (1.99 euros, USD 2.64) per $\mathrm{m}^{3}$ for the whole manufacture industry although there are important differences between sectors. This result allows us to predict that water markets would redistribute water from the agrarian sector to the 
industry in case of scarcity of water. So, water markets are an instrument that can allow users to get profitable agreements to overcome drought or to reduce risk aversion in an amicable way.

The price elasticity of water obtained for the whole industry, -1.1, would indicate that tariff policy would be an effective tool to get reductions in industrial water demand. Given the scarcity of water in some areas of Chile, this is an instrument that has to be taken into account in order to get water savings.

The analysis of other sectors as mining industry and households remain as extensions of this paper that could provide better knowledge and picture of foreseeable effects of water markets implementation in case of scarcity.

\section{BIBLIOGRAPHY REFERENCES}

ALBIAC, J., HANEMAN, M., CALATRAVA, J., UCHE, J. y TAPIA, J. (2006). "The rise and fall of the Ebro water transfer". Natural Resources Journal 46, pp. 727-757.

ARBUÉS, F., GARCÍA-VALIÑAS, M.A. y VILLANÚA, I. (2010). "Urban Water Demand for Service and Industrial Use: The case of Zaragoza". Water Resources Management 24, pp. 4033-4048.

BABIN, F., WILLIS, C.E. y ALLEN, P.G. (1982). "Estimation of substitution possibilities between water and other production inputs". American Journal of Agricultural Economics 64, pp. 149-152.

BEAMONTE CÓRDOBA, E., CASINO MARTÍNEZ, A. y VERES FERRER, E.J. (2010). "Medición de la calidad del agua mediante indicadores. Relación entre éstos y las tarifas de abastecimiento". Estudios de Economía Aplicada, Vol 28(2), pp. 357-374.

BISWASS, A.K. (1997). "Water Development and Environment" en Asit K. Biswas, (ed.): Water Resources: Environmental Planning, Management and Development (pp. 1-37). New York: McGraw-Hill.

CALATRAVA, J. y GARRIDO, A. (2005). "Modelling water markets under uncertainty water supply". European Review of Agricultrual Economics, 32, pp. 119-142.

CALATRAVA LEYVA, J. y SAYADI, S. (2005). "Economic valuation of water and willingness to pay analysis with respect to tropical fruit production in southeastern Spain". Spanish Journal of Agricultural Research 3, pp. 25-33.

CARPIO, C.E., RAMÍREZ, O.A. y BOONSAENG, T. (2011). "Potential for Tradable Water Allocation and Rights in Jordan". Land Economics, 87(4), pp. 595-609.

CHRISTENSEN, L., JORGENSON, D. y LAU, L. (1973). "Transcendental logarithmic production function frontiers". Review of Economic and Statistics, 55, pp. 29-45.

COBB, C. y DOUGLAS, P. (1928). "A theory of production". American Economic Review, 18, pp. 139-165.

DEL VILLAR, A. (2010). "Los precios de los servicios del agua. Un análisis prospectivo de demanda sobre los usos domésticos". Estudios de Economía Aplicada, 28(2), pp. 333356. 
DEROOY, Y. (1974). "Price Responsiveness of the Industrial Demand for Water". Water Resources Research 10(3), pp. 403-406.

DUPONT, D.P. y RENZETTI, S. (2001). "The Role of Water in Manufacturing". Environmental and Resource Economics, 18, pp. 411-432.

FERES, J. y REYNAUD, A. (2005). "Assessing the Impact of Environmental Regulation on Industrial Water Use: Evidence from Brazil". Land Economics, 81(3), pp. 396-411.

FERES, J., REYNAUD, A. y THOMAS, A. (2012). "Water reuse in Brazilian manufacturing firms". Applied Economics, 44, pp. 1417-1427.

GIBBONS, D.C. (1986). The Economic Value of Water. Resources for the Future. Washington D.C.

GREBENSTEIN, C.R. y FIELD, B.C. (1979). "Substituting for water inputs in US manufacturing". Water Resources Research 15, pp. 228-232.

GRIFFIN, R.C. (2006). Water Resource Economics: The Analysis of Scarcity, Policies and Projects. Cambridge, MA: MIT Press.

KUMAR, S. (2006). "Analysing industrial water demand in India: An input distance function approach". Water Policy 8, pp. 15-29.

MINISTERIO DE OBRAS PÚBLICAS. Gobierno de Chile. Estrategia Nacional de Recursos Hídricos 2012-2025. http://www.mop.cl/documents/enrh_2013_ok.pdf

MORAN, D. y DANN, S. (2008). "The economic value of water use: Implications for implementing the Water Framework Directive in Scotland". Journal of environmental Management 87, pp. 484-496.

OLMSTED, S.M. (2010). "The Economics of Managing Scarce Water Resources". Review of Environmental Economics and Policy, 4(2), pp. 179-198.

PAELINCK, J.H.P. y MUR, J. (2018). "Some Issues on the Concept of Causality in Spatial Econometric Models". Estudios de Economía Aplicada, 36(1), pp. 107-118.

RAMSEY, J.B. (1974). Classical model selection through specification error tests. Frontiers of econometrics, (Ed.) P. Zarembka, New York Academic Press, New York.

RENZETTI, S. (1988). "An econometric study of industrial water demands in British Columbia, Canada". Water Resources Research 24, pp. 1569-1573.

RENZETTI, S. (1992). "Estimating the structure of industrial water demands: The case of Canadian manufacturing". Land Economics 68, pp. 396-404.

RENZETTI, S. (1993). "Examining the difference in self and publicly supplied firms' water demands". Land Economics, 69, pp. 181-188.

REYNAUD, A. (2003). "An econometric estimation of industrial water demand in France". Environmental and Resource Economics, 25, pp. 213-232.

RIGBY, D., ALCÓN, F. y BURTON, M. (2010). "Supply uncertainty and the economic value of irrigation water". European Review of Agricultural Economics, 37(1), pp. 97-117.

ROMÁN SÁNCHEZ, I.M., CARRA, I. y SÁNCHEZ PÉREZ, J.A. (2013). "El uso sostenible del agua: Tributos medioambientales y nuevos procesos de descontaminación mediante energías renovables". Estudios de Economía Aplicada, 31(1), pp. 197-216.

ROSEGRANT, M.W., RINGLER, C., MCKINNEY, D.C., CAI, X., KELLER, A. y DONOSO, G. (2000). "Integrated economic-hydrologic water modelling at the basin scale: the Maipo river basin". Agricultural economics, 24, pp. 33-46.

TOBARRA GONZÁLEZ, M.A. (2013). "Factores explicativos de la demanda municipal de agua y efectos en el bienestar de la política tarifaria. Una aplicación a la cuenca del Segura". Estudios de Economía Aplicada, 31(2), pp. 577-596. 
VILJOEN, M.F., DUDLEY, N.J. y GAKPO, E.F.Y. (2000). "A methodological perspective on valuing water: A comparison between linear programming and stochastic dynamic programming". Agrekon, 39(4), pp. 471-483.

SUPERINTENDENCIA DE SERVICIOS SANITARIOS. Gobierno de Chile. Informes de Gestión del Sector Sanitario 1995-2014.

TEEPLES, R. y GYLER (1987). "Comments on "Estimating Demand by Self-Supplying Firms by Joseph A. Ziegler and Stephen E. Bell". Water Resources Research 23(5), pp. 148-151.

TURNOVSKY, S. (1969). "The Demand for Water: Some Empirical Evidence on Consumers' Response to a Commodity in Uncertain Supply". Water Resources Research 5(2), pp. 350-361.

WANG, H. y LALL, S. (2002). "Valuing water for Chinese industries: a marginal productivity analysis". Applied Economics, 34, pp. 759-765.

WILLIAMS, M. y SUH, B. (1986). "The demand for urban water by customer class". Applied Economics 18, pp. 1275-1289.

XIMING, C., RINGLER, C. and YOU, J.Y. (2008). "Substitution between water and other agricultural inputs: Implications for water conservation in a River Basin context". Ecological Economics, 66, pp. 38-50.

ZIEGLER, J. and BELL, S. (1984). "Estimating the demand for intake water by selfsupplied firms". Water Resources Research 20, pp 4-8. 


\section{Annex}

Table 1

Variables used in the manufacture sector empirical analysis

\begin{tabular}{|l|l|r|r|}
\hline \multicolumn{1}{|c|}{ Variable } & \multicolumn{1}{c|}{ Units } & \multicolumn{1}{c|}{ Mean } & \multicolumn{1}{c|}{ Standar deviation } \\
\hline Production & thousands of pesos & $8,348,799.21$ & $31,774,795.7$ \\
\hline Water & $\mathrm{M}^{3}$ & $97,184.01$ & $1,623,236.7$ \\
\hline Capital & thousands of pesos & $12,516,417.20$ & $118,454,806$ \\
\hline Labour & Number of workers & 112.67 & 267.8 \\
\hline O.s. of energy & thousands of pesos & $166,626.25$ & $1,017,164$ \\
\hline Electric energy & KWh & $19,522.25$ & $766,339.5$ \\
\hline Raw materials & thousands of pesos & $4,382,396.24$ & $20,827,376.5$ \\
\hline
\end{tabular}

Source: Own elaboration.

Table 2

Cobb-Douglas model estimate

\begin{tabular}{|c|c|c|c|c|}
\hline Variable & Coefficient & Std. Error & t-Statistic & Prob. \\
\hline C & 4.253667 & 0.077304 & 55.02505 & 0.0000 \\
\hline LnW & 0.018019 & 0.006271 & 2.873132 & 0.0041 \\
\hline LnK & 0.075505 & 0.005796 & 13.02676 & 0.0000 \\
\hline LnL & 0.364621 & 0.013395 & 27.22119 & 0.0000 \\
\hline LnEN & 0.028700 & 0.006404 & 4.481293 & 0.0000 \\
\hline LnE & 0.047661 & 0.006966 & 6.842065 & 0.0000 \\
\hline LnM & 0.524125 & 0.008086 & 64.82025 & 0.0000 \\
\hline R-squared & 0.935857 & S.D. dependent var & & 14.20874 \\
\hline Adjusted R-squared & 0.935692 & Akaike info criterion & & 1.705061 \\
\hline S.E. of regression & 0.432387 & Schwarz criterion & & 1.163998 \\
\hline Sum squared resid & 435.9879 & F-statistic & & 5670.1897 \\
\hline Log likelihood & -1354.296 & Prob (F-statistic) & \\
\hline Durbin-Watson stat & 1.896934 & \multicolumn{3}{|l}{} \\
\hline
\end{tabular}

Source: Own elaboration.

Table 3

Elasticity of production, Marginal value of water and Price elasticity of water for major industrial subsectors

\begin{tabular}{|l|c|c|c|}
\hline \multicolumn{1}{|c|}{ Subsector } & $\begin{array}{c}\text { Elasticity of } \\
\text { production }\end{array}$ & $\begin{array}{c}\text { Marginal value of } \\
\text { water }\end{array}$ & $\begin{array}{c}\text { Price elasticity of } \\
\text { water }\end{array}$ \\
\hline Food and Beverage & 0.01514557 & 3.03940675 & -1.29 \\
\hline Chemistry, couch and plastics & 0.04186056 & 5.32441575 & -0.89 \\
\hline $\begin{array}{l}\text { Metal products, machinery and } \\
\text { equipment }\end{array}$ & 0.01293781 & 7.85829304 & -0.74 \\
\hline Cellulose, paper and prints & 0.06606663 & 1.01732199 & -3.17 \\
\hline Textile, garments and leather & 0.00514487 & 2.95621011 & -0.31 \\
\hline Wood and furniture & 0.06154378 & 13.44753000 & -1.12 \\
\hline Manufacture Industry & 0.01577821 & 2.8 & -1.1 \\
\hline
\end{tabular}

Source: Own elaboration. 
